\title{
GOVERNING WATER AS A COMMON GOOD IN THE MEKONG RIVER BASIN: issues of scale
}

\author{
Transforming Cultures eJournal, \\ Vol. 1 No. 2, June 2006 \\ http://epress.lib.uts.edu.au/journals/TfC
}

\author{
Philip Hirsch \\ School of Geosciences \\ University of Sydney
}

\begin{abstract}
Transboundary water governance has received special attention in the wake of the World Bank vice-president Ismail Serageldin's famous prediction in 1995 that, "if the wars of this century were fought over oil, the wars of the next century will be fought over water". ${ }^{1}$ The water wars scenario ensures that in the world's more than 260 river basins that flow across national boundaries, primary attention is given to managing water as an international commons. A framework for such transboundary management has been in place more or less continuously in the Mekong for half a century, and it would appear that water has indeed been a force for cooperation even when brutal conflict has torn at the region.
\end{abstract}

Despite the appearance of successful basin-scale management, inter-governmental management of water as an international commons in a transboundary river basin context can also hide some troubling ways in which water as a commons is eroded in the process of development. This paper considers common property dimensions of water and the livelihood systems that they support at multiple scales within the Mekong. It goes on to look at ways in which these are impacted upon by bureaucratisation, infrastructure and commodification processes. Ironically, basin organisations can both enhance and undermine governance for the common good, depending on how they deal with commonality of interest in freshwater at various scales. The paper draws on brief case studies of current trends in water governance including river basin organisations in the Mekong (the Mekong River Commission and River Basin Committees at national levels), of infrastructure (Thailand's proposed Water Grid and Laos' Nam Theun 2 dam) and of commodified notions of water (as a development resource and as a scarce commodity to be managed through market mechanisms).

\section{Introduction}

Two hundred and sixty one of the world's river basins are shared by more than one country. Transboundary water management is one of the key areas in which there is interest in what may be considered the transnational commons. Unlike the global

\footnotetext{
${ }^{1}$ See for example Global Policy Forum 2002 at

$<$ http://www.globalpolicy.org/ngos/role/policymk/conf/2002/0827water.htm>.
} 
commons of the oceans, the atmosphere, Antarctica or biodiversity, transboundary rivers involve management by a set number of states within their particular political relations. Like the global commons, however, managing water across and within borders as a common good raises some key issues of scale. In particular, questions arise when the development framework set in place by transnational institutions has implications for more local commons management of the same resource.

In their critique of the Brundtland Commission's "Our Common Future", The Ecologist turned the issue into a question of "Whose Common Future?". 2 The main area of concern here is the construction of a global commons that arrogates wisdom and management of these commons to global institutions such as the World Bank. In so doing, biodiversity and other resources deemed to have world heritage value are deemed too important for local management. The use of neo-liberal property rights regimes and market mechanisms to deal with perceived local "tragedies of the commons"3 sees development predicated on enclosure, as critiqued in a number of publications by the radical environmental and social justice think-tank Cornerhouse, and this critique can be extended to mainstream environmental governance as enclosure. ${ }^{4}$

In this presentation, I examine parallel issues in what might be termed a "bioregional transboundary commons", in the sense that the Mekong River Basin is a transnational area defined by a natural boundary within which the commonality of the shared resource is based on the interconnected nature of the river system. I start with an overall account and history of the framework for managing the Mekong as a shared resource, and then consider how development options associated with this framework pose questions for more localised commons, their tenure and their management. This is illustrated through case studies in water governance, water infrastructure and commodification of water.

\footnotetext{
2 The Ecologist (1993) "Whose Common Future? Reclaiming the Commons". London: Earthscan.

${ }^{3}$ G. Hardin (1968) "The Tragedy of the Commons" in Science 162:1243-1248, December 13.

${ }^{4}$ Zerner (2002) People, Plants, and Justice: The Politics of Nature Conservation. New York: Blackwell
} 


\section{Transnational commons in water and their management: the Mekong}

Transboundary management of rivers whose waters and catchments are shared by several countries is clearly an important concern. This concern was expressed dramatically in 1995, when the then World Bank Vice-President stated famously that, "if the wars of this century were fought over oil, the wars of the next century will be fought over water". 5 Since that time, there has been much critique of such an analysis, in part because it is seen to be alarmist, in part because shared rivers have in fact often served as a basis for cooperation rather than conflict, ${ }^{6}$ and in part because the primary dimensions and scale of conflict over water are more locally and socially than geopolitically constructed. ${ }^{7}$

The Mekong River and the territory in its Basin is shared by six countries: China, Burma, Thailand, Lao PDR, Cambodia and Vietnam. Seven hundred and ninety five thousand square kilometres in area, the Mekong is the world's $12^{\text {th }}$ longest river $(4800$ $\mathrm{km}), 8^{\text {th }}$ largest in terms of average freshwater discharge $\left(475\right.$ billion $\left.\mathrm{m}^{3}\right), 2^{\text {nd }}$ most biodiverse (approximately 1700 fish species), and it maintains the world's largest freshwater fishery $(2-3$ million tons annually, $80-90 \%$ of which comes from artisanal capture fisheries, providing between $40 \%$ and $80 \%$ of animal protein in the diets of the rural poor dependent on this resource).

The Mekong has been managed as a transboundary basin for longer than most international river systems, despite the region having been ravaged by geopolitical conflict from the 1950s to 1980s. The Mekong Committee was established in 1957, went into abeyance after Cambodia withdrew in 1975 under Pol Pot, was reconstituted as the Interim Mekong Committee in 1978, and was reinvented as the Mekong River Commission (MRC) under the Agreement for the Cooperation for Sustainable Development of the Mekong River Basin in 1995. The Mekong cooperation framework has only been partial, as the two upstream countries - China and Burma - have never joined. It has also been associated for much of its life with planning and promotion of large scale water resource infrastructure, notably large dams, although conflict in the

\footnotetext{
${ }^{5}$ Refer to footnote 1.

${ }^{6}$ Wolf (1998) "Conflict and cooperation along international waterways", in Water Policy 1(2): 251-265.

7 J. Boesan \& H.M. Ravnborg (2004) From Water "Wars” to Water "Riots" - Lessons from Transboundary Water Management. Copenhagen: Danish Institute for International Studies.
} 
region meant that little of this ever got built. Since the early 1990s, however, dams have been very much back on the agenda, even though the MRC itself has moved away from hydropower planning and development as a driving activity.

The transboundary nature of the Mekong River tends to supersede many other ways in which, and levels at which, water and resources or livelihoods dependent on it are held and managed in common. ${ }^{8}$ Water as common property is manifested in traditional irrigation structures (eg muang-faai in Thailand and Laos), in community-based artisanal fisheries and in the commons of seasonally flooded lands and forests that have great livelihood significance for riparian communities. There are thus multiple local commons associated with water that are, at best, secondary considerations in transboundary river basin management.

\section{Development and the water commons: issue of scale}

Intergovernmental management of the Mekong as a transboundary commons has been inseparable from the agenda of development. In a region three of whose economies (Vietnam, Laos and Cambodia) are still among the poorest in the world when measured on a per capita income basis, it is not surprising that development dominates all else. Further, development in the Mekong cooperation context has been closely tied with dominant geopolitical agendas. An early illustration of this can be seen on the cover of National Geographic in December 1968, where the Mekong was featured as a "river of terror [communism] and hope [dams]". The latter were seen as the hope to pull the region out of poverty and hence tug remote rural areas out of the sway of subversive ideology preying on poverty and hopelessness. While this belongs to a past ideological era in terms both of geopolitical and environmental understandings, developmentalism lives on, for example in the Asian Development Bank's (ADB) discourse on reaping "peace dividends" through its infrastructure-oriented Greater Mekong Subregion development program. ${ }^{9}$

\footnotetext{
${ }^{8}$ E.g. Ahmed \& Hirsch (2000) "Common property in the Mekong: issues of sustainability and subsistence." ICLARM and AMRC, The University of Sydney.

${ }^{9}$ Pante (1996) "Investing in regional development: Asian Development Bank", in Stensholt, B. (ed.) Developing the Mekong Subregion. Clayton: Monash Asia Institute.
} 
The question that arises is what alternative conflicts are generated, and what other common property arrangements are impacted upon, by the mainstream development agenda associated with transboundary cooperation and MRC- or ADB-style management? In the remainder of this presentation, I suggest and illustrate three key areas of tension that are all closely related to mainstream development: water governance, water infrastructure and water as commodity.

\section{Water governance}

Water governance has become an important part of water reforms and of development assistance in the water sector. In many respects, this is a widely welcomed move away from old-style "hardware" financing dominated by engineering projects, toward the "software" of seeking equitable, efficient and sustainable approaches to water management. High on the agenda of water governance in its river basin context is the establishment of river basin organisations. Ironically, however, river basin organisations can both enhance and undermine governance for the common good, depending on how they deal with commonality of interest in freshwater at various scales. Bureaucratisation of process is one threat to managing the local commons in water. Issues of representation present another. In the Mekong, these can be illustrated through governance at the level of the $\mathrm{MRC}$, and through the river basin committees being established in Thailand and mooted elsewhere.

As an intergovernmental organisation, the MRC is in principle owned and governed by its member countries (the four lower Mekong nations of Lao PDR, Thailand, Cambodia and Vietnam). In fact, as an organisation whose budget is almost entirely dependent on foreign grant aid, the MRC remains aid donor-driven. The nature of governmental control through the Ministerial Council and Joint Committee is such that two major barriers exist to representation of the local commons in water and fish. First, it is Water Resources departments and related ministries who represent "national interests" on the MRC Council, lending a strong bias toward construction and "developing" the river. Cambodia is represented by the Minister for Water Resources and Meteorology; Lao PDR is represented by the Minister of the Prime Minister's Office; Thailand is represented by the Ministry of Natural Resources and Environment, on the basis that it houses the Department of Water Resources; and Vietnam is represented by the Ministry of Agriculture and Rural Development, home to the Department of Irrigation. Second, 
the diplomacy and international relations bound up in the organisation lead to a culture of non-interference, non-confrontation and deference of weaker to stronger countries. This is illustrated by the difficulty of indigenous community voices and civil society interests being heard in a case where lives and livelihoods have been badly damaged by Vietnam's Yali Falls Dam and its downstream impacts in Cambodia, which have destroyed fisheries, livestock and riverside gardens. MRC did establish a governmentto-government forum to address this case, but it has not had the capacity or provided the access for local communities to put their grievances in the trans-border arena in which this governance problem is set. ${ }^{10}$

At the national level, establishment of River Basin Committees raises similar concerns. At one level, RBCs are a progressive step that establish a basis for administration within bioregional rather than provincial administrative boundaries, based on integrated water resource management principles. However, there is little or no articulation with more local structures, such as traditional irrigation systems. Half the representation on RBCs is by ex-officio government staff. The other half comes from non-governmental representatives such as chambers of commerce and an ad-hoc mixture of respected persons and organisations, but without systematic village-based representation. As a result, RBCs tend to be seen as an instrument of the Department of Water Resources and as a means to secure funds to build weirs, small reservoirs and other water infrastructure rather than to establish or enhance the management of water as a local commons.

\section{Water infrastructure}

The greatest physical threat to common property values of water at a livelihood level is the further construction of large scale infrastructure. Since its establishment in 1995, MRC has certainly moved away from a dam-first mentality toward river basin development, and indeed the largest donor funding has gone into the fisheries and environment programs. More recently, there has been a return to an investment-led notion of sustainable river basin development, with the current CEO of the Secretariat seeing the role of the Commission as an "investment facilitator" - albeit "with due

\footnotetext{
${ }^{10}$ Hirsch \& Wyatt (2004) "Negotiating local livelihoods: scales of conflict in the Se San River Basin", in Asia Pacific Viewpoint 45(1).
} 
regard for the environment". ${ }^{11}$ While some have seen the large scale infrastructure approach as a thing of the past, and the World Commission on Dams seemed to signal a closure of the build first, ask questions later approach to impoundment and diversion of rivers, there is something of a resurgence in dams and diversions in the Mekong. Two current projects illustrate this quite dramatically.

At the end of March 2005, the Board of Directors of the World Bank voted in favour of Bank support for the Nam Theun 2 dam in Laos, in the form of loans and sovereign risk guarantees. This marks the culmination of a heated debate that has raged over more than a decade, ${ }^{12}$ and it also marks a return by the Bank to what it now terms "high risk, high return" projects. That the risks and returns fall on different sets of shoulders is, in principle, supposed to be taken care of by better planning, resettlement and compensation programs. Nevertheless, the fact remains that this project, which will be the largest transboundary energy project in Asia (almost all the electricity generated is for sale to Thailand) and requires an investment roughly equivalent to the annual GDP of the country in which it is being built, involves a loss of public resources managed in common by affected communities and changes in how they will be managed. These include not only the sections of the Nam Theun River, forests and farmlands of 6000 people from ethnic minority groups that will go under the $450 \mathrm{sq} \mathrm{km}$ reservoir, but also the downstream fisheries on the Xe Bang Fai River, accessed by up to 100,000 people and river bank gardens along the same river. The proposed compensation for loss of these common resources is an unspecified "replacement" of lost fisheries through aquaculture ponds. Another loss of local commons will be in the use of upstream forest lands in the headwaters area by remote indigenous minorities whose livelihood activities will be circumscribed in the name of protecting both biodiversity (a global common) and the investment in the reservoir in the form of "ecosystem services".

A second major infrastructure project shortly to get underway is the Thai Water Grid (the common term for a project whose official name translates as the "Sustainably Holistic Water Management Project”. Requiring an investment of some 200 billion

\footnotetext{
${ }^{11}$ MRC Annual Report 2004. Vientiane: The Mekong River Commission, p. 29.

${ }^{12}$ Hirsch (1991) "Environmental and social implications of Nam Theun Dam, Laos, Working Paper No. 5". Economic and Regional Restructuring Research Unit, Departments of Economics and Geography: University of Sydney; and Hirsch (2002) "Global Norms, Local Compliance and the Human RightsEnvironment Nexus: A Case Study of the Nam Theun II Dam in Laos”, in Zarsky, L. (ed.) Human rights and the environment: conflicts and norms in a globalizing world. London: Earthscan.
} 
baht (about AUD\$7 billion), the project is designed to address Thailand's water crisis by linking river basins that have surplus water with those that have insufficient watera scheme reminiscent in some ways of our own Snowy Mountains project or of the idea of taking water from the Kimberley to Perth, and mirrored in India's river linking program and China's South-North diversions linking the Yangtze waters with the moribund Yellow River. The Water Grid would also access water from Cambodia, Laos and Burma. In the case of Laos, this involves piping water from the Nam Ngum and Xe Bang Hieng tributaries under the Mekong to water the dry northeastern region. The reason for not taking water straight out of the Mekong itself is bound up in the water sharing rules under the 1995 Agreement, which would make such a move a multilateral rather than bilateral matter among Mekong countries. In fact, the existing but toned down Khong-Chi-Mun diversion scheme is based on a somewhat similar principle, and some of the most controversial projects in Thailand have been part of this, including Pak Mun and Rasi Salai Dams. Indicative of the implications of such "water sharing" for the local commons are the destruction of artisanal fisheries in the case of Pak Mun and of the seasonally flooded gallery forests (paa thaam) in the case of Rasi Salai, which used to provide an important dry season food source for affected communities but have not been taken into account in project planning by the very fact of their being common property and therefore without official individual land title.

\section{Water as commodity}

There is a fundamental tension between water as a common resource and water as commodity. This has been debated since the signing of the 1992 Dublin Principles that established an international understanding of the economic nature of water. Water has been established as commodity, albeit in a highly contested manner, as part of the mainstream development thrust in the Mekong region. Two dimensions of water as commodity stand out in particular.

First, the pressure by some external development agencies to price water as part of neoliberal reforms packages has led further to discussion of water as a tradeable - and by implication alienable - commodity. The Asian Development Bank attempted to set conditionalities as part of its 1999 Agricultural Sector Program Loan (ASPL) in Thailand that would require water pricing. Immediately this provoked a backlash by NGOs and farmer groups already facing financial hardship due in the wake of the 1997 
financial crisis (which, ironically, the ASPL was designed to alleviate). In fact, the notion of water as a free good is something of a myth - villagers have long paid for water by mobilizing labour, materials and "social capital" in local irrigation systems and have paid for the use of water through rice or cash payments to locally elected irrigation managers in muang-faai systems. Elsewhere, locally managed pump irrigation attracts a fee that farmers have willingly paid and managed in common. Thus, the issue of pricing per se is subsidiary to the imposition of new centrally imposed charges, and in particular to the question of alienable water rights.

A second dimension of water as commodity is the valorizing of rivers inherent in large dam projects, particularly as the private sector now makes the running on projects such as Nam Theun 2 as described above. Ironically, part of the discourse of Nam Theun 2 "consultation teams" involved in the public relations work to bring affected communities on-side was to talk of "rivers of gold and silver" wealth to the country and its citizens alike once projects like Nam Theun 2 get off the ground. Here, the national "common good" evoked through the "national interest" takes precedence over and usurps the local commons.

\section{Conclusion}

Transboundary rivers such as the Mekong are, and need to be, managed in common. However, without a scale sensitivity to what commonality of interest and the commons themselves mean and imply, there is a tendency for the transnational (i.e. broad-scale) commons to dominate and become tied closely to a mainstream developmentalism. In this presentation, I have tried to demonstrate some of the dilemmas this creates for the local commons associated with water in its river basin context.

There is nothing to suggest that concern for transboundary commons is incompatible with an understanding of, and respect for, the commons at other scales. Rather, the status quo, particularly as manifested in the governance structures associated with large scale and bureaucratically and developmentally inclined river basin institutions, mitigates against simultaneous multi-scale understandings of water as a shared and jointly managed resource. Progressive moves toward a scaled approach to governance

\footnotetext{
${ }^{13}$ Dateline (1996) Dam Destiny. Sydney: SBS Television.
} 
that incorporates civil society and community interests can only serve to enhance equitability and sustainability in managing these commons.

\section{References}

Ahmed, M. \& Hirsch, P. (eds.) (2000) "Common property in the Mekong: issues of sustainability and subsistence." ICLARM and AMRC, The University of Sydney.

Boesen, J. \& Ravnborg, H.M. (2004) From Water "Wars" to Water "Riots" - Lessons from Transboundary Water Management. Copenhagen: Danish Institute for International Studies.

Dateline (1996) Dam Destiny. Sydney: SBS Television.

Hardin, G. (1968) “The Tragedy of the Commons” in Science 162:1243-1248.

Hirsch, P. \& Wyatt, A. (2004) "Negotiating local livelihoods: scales of conflict in the Se San River Basin.” Asia Pacific Viewpoint 45(1).

Hirsch, P. (1991) Environmental and social implications of Nam Theun Dam, Laos, Working Paper No. 5. Economic and Regional Restructuring Research Unit, Departments of Economics and Geography, University of Sydney.

_ (2002) "Global Norms, Local Compliance and the Human RightsEnvironment Nexus: A Case Study of the Nam Theun II Dam in Laos", in Zarsky, L. (ed.) Human rights and the environment: conflicts and norms in a globalizing world. London: Earthscan.

MRC (2004) Annual Report 2004. Vientiane: The Mekong River Commission.

Pante, F (1996) "Investing in regional development: Asian Development Bank", in Stensholt, B. (ed.) Developing the Mekong Subregion. Clayton: Monash Asia Institute.

The Ecologist (1993) Whose Common Future? Reclaiming the Commons. London: Earthscan.

Wolf, A. (1998) "Conflict and cooperation along international waterways." Water Policy 1(2): 251-265.

Zerner, C. (ed.) (2002) People, Plants, and Justice: The Politics of Nature Conservation. New York: Blackwell. 